\title{
Integrating waste-to-energy in Copenhagen, Denmark
}

1 Tore Hulgaard MSc, PhD

Technical Manager at Energy-from-Waste Department, Ramboll Energy, Copenhagen, Denmark
2 Inger Søndergaard MSc

Head of Department at Energy-from-Waste Department, Ramboll Energy, Copenhagen, Denmark
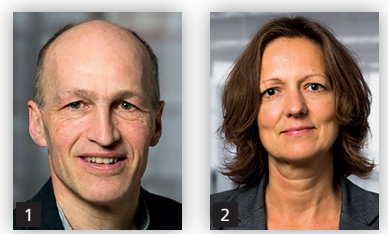

Completed in 2017, the new Amager Bakke waste-to-energy project in Copenhagen, Denmark, is the largest of its kind in the Nordic countries. Its revolutionary design, including ski slopes on the roof and climbing walls, helps to integrate the facility with the city. As explained in this paper, the plant also has ultra-high energy efficiency and environmental performance, which required innovative solutions. Achievements include combined heat and power production with a net thermal efficiency of $107 \%$ and air emissions generally below $10 \%$ of limit values. Recovery of over $200000 \mathrm{t}$ of condensate a year could also replace other water resources, such as district heating water and make-up water.

\section{Introduction}

The new Amager Bakke waste-to-energy facility is located in a residential suburb of Copenhagen in Denmark (Figure 1). Put into operation in 2017 , the $80 \mathrm{~m}$ high roof is the highest public viewpoint in the city, and the slope of the roof is made available for skiing and other recreational purposes in 2018. The facade also has a challenging climbing wall.

Inside the building is a highly efficient combined heat and power (CHP) plant. The fuel is residual waste - that is, waste that is nonrecyclable, primarily originating from the greater Copenhagen area particularly from the five municipalities owning the facility through an intermunicipal company. Other fuel sources include industrial waste and biomass fractions that are too difficult to handle in conventional biomass fired facilities.

This paper focuses on technical aspects of Amager Bakke, which is a bar-raising project in several respects; for example by having a projected total net energy efficiency of $107 \%$, and outstanding

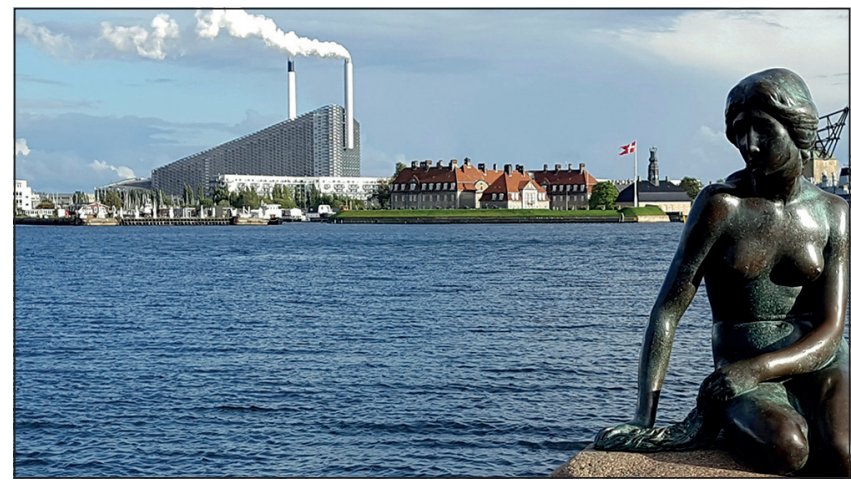

Figure 1. Amager Bakke waste-to-energy facility is a prominent addition to the Copenhagen skyline environmental performance. It includes the potential for further recycling and recovery of materials. For instance, $40 \%$ of the incoming waste can be recovered as ultra-clean reusable water, and metals are recovered from the bottom ash, of which the remaining matter is reused for road construction, and its mass makes up around $15 \%$ of the incoming waste.

\section{About Amager Bakke}

Amager Bakke was established by Amager Ressource Center (ARC) adjacent to ARC's existing facility. ARC is an intermunicipal resource company owned by five municipalities in the Greater Copenhagen area. The company receives and processes waste from approximately 600000 residents in the five owner municipalities and 68000 businesses (ARC, 2017) and provides recycled materials, electricity and district heating to the city.

The new facility replaces ARC's 47 year old waste treatment facility, which entailed high maintenance costs, had only moderate energy efficiency and did not meet contemporary standards for occupational health and safety. The new plant was based on a comprehensive financial and technology review process. The final solution was found to be the best solution with respect to both total economy and lifecycle analysis of the environmental impact.

The financial framework represents a key driver in reaching the high energy recovery and environmental performance. Investments in improved efficiency prove their value when allowed to work over a long financial planning period and with moderate demands for return on investment. The investment of around $€ 500$ million was financed by a loan guaranteed by the five municipalities. The most important framework conditions were

- connection to a large district heating network that allows sale of heat year-round at almost full load (no cooling is accepted)

- economic value of electrical power and heat is at ratio $2: 1$ 


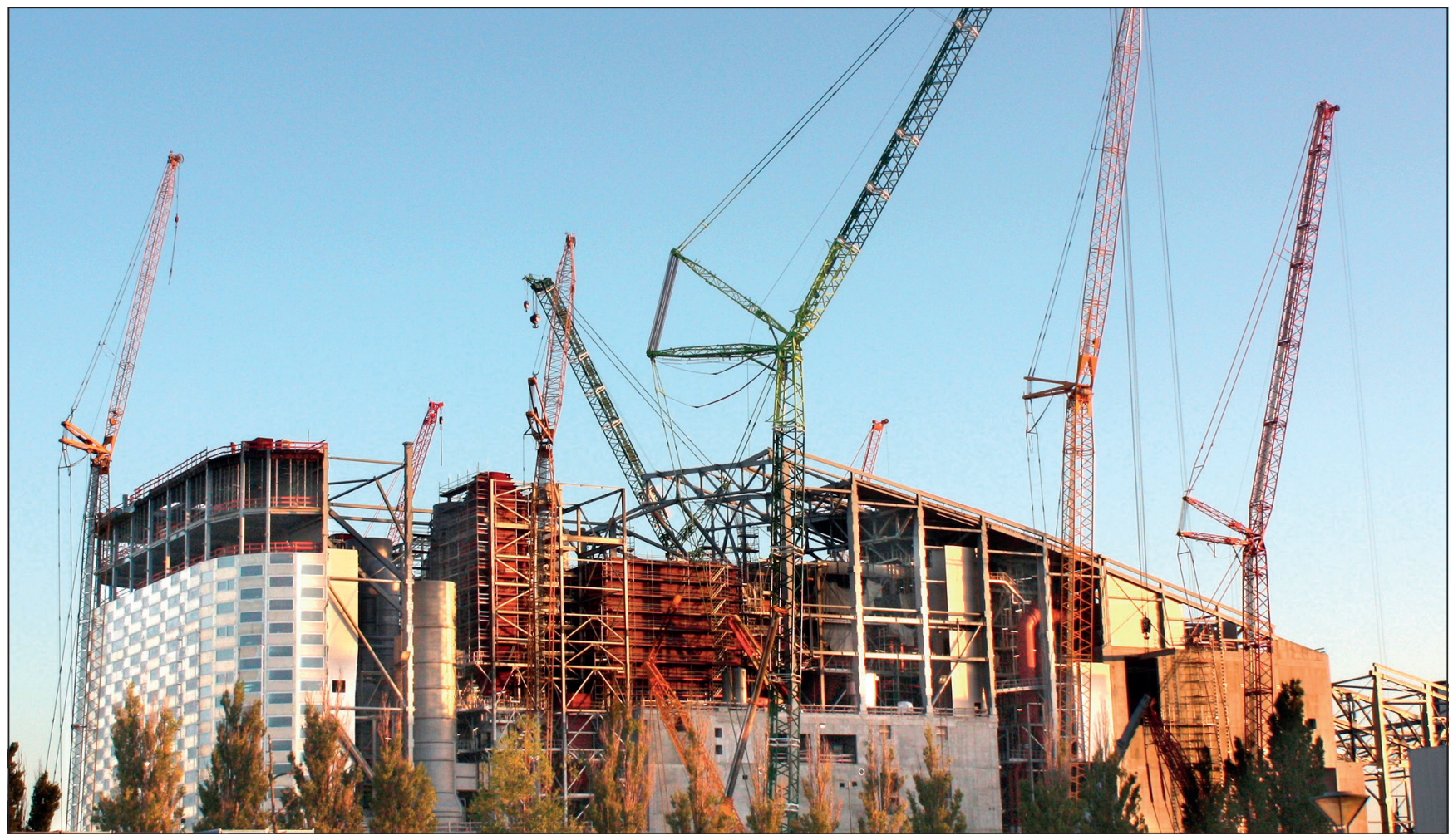

Figure 2. The $80 \mathrm{~m}$ tall plant under construction - the sloping roof has a public park, ski slopes and climbing wall

- discharge of treated process wastewater is an opportunity

- nitrogen oxides $\left(\mathrm{NO}_{\mathrm{x}}\right)$ emission tax of $€ 3 \cdot 3 / \mathrm{kg}$.

Furthermore, the successful integration of the plant in the city and its economic success rely on legislative and organisational frameworks that facilitate co-operation between stakeholders. Essential factors are the guaranteed waste delivery, offtake of heat, municipal guarantees of loans and the agreement of the owners to a high degree of public access to the facility resulting in an architectural development of ideas.

The design of Bjarke Ingels Group (BIG), which included a rooftop ski slope, was selected. The tendering and construction was led by a project team at ARC. Ramboll was selected as a technical consultant for elaborating technical analyses and development of concepts for electromechanical supply of the waste-to-energy facility. More than 1000 pages of technical memos led to the conceptual design and functional requirements of the technical specification in the tender documents, which were divided into five main electromechanical lots covering the respective systems of the furnace, boiler, turbine, generator and flue gas treatment, together with electrical installations and control and monitoring systems. The civil engineering was led by the engineering consultant MOE, which carried out the detailed design of construction, the works of which were tendered to a number of contractors.

The main electromechanical contracts were signed in the autumn of 2012, operation started in mid-2017, and trial run, and take-over is expected in 2018. Figures 2 and 3 show the construction process, exemplified by reception and mounting of wet scrubber parts.

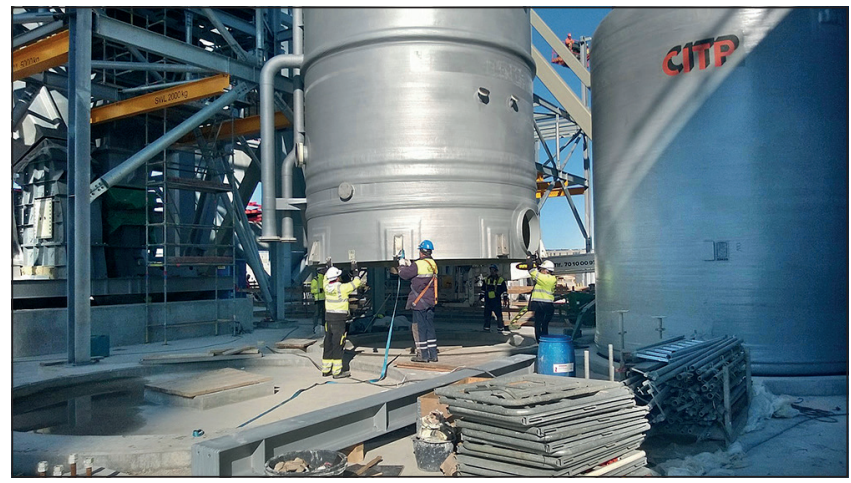

Figure 3. Positioning lower part of a scrubber

\section{Recreational opportunities}

Usually public access to waste-to-energy facilities is limited to guided tours of limited parts of the premises. At Amager Bakke the roof and parts of the facade will be used to create a recreational park (Gustavsson, 2017). The park consists of several mountainrelated activities, such a $10000 \mathrm{~m}^{2}$ dry-ski slope, consisting of four adjacent ski slopes for beginners as well as experts, each with its own ski-lift.

One third of the $16000 \mathrm{~m}^{2}$ roof will be used to create a large green mountain landscape, where visitors can hike, run and enjoy the scenery of the green landscape with trees, bushes and plants. 
From the roof terrace $77 \mathrm{~m}$ above ground visitors can enjoy the view over Øresund and central Copenhagen and buy food from the street-food kitchen. A part of the building's facade will be used to erect an $80 \mathrm{~m}$ tall climbing wall.

Development of the recreational park has been done in close collaboration with over 30 local sports-clubs and organisations. It has been built by The Amager Bakke Foundation and is expected to open in 2018.

\section{Energy recovery and efficiency}

One precondition for the very high energy recovery is the access to the large district heating network of Copenhagen. District heating in Denmark has a long history, going back to 1903 when Denmark built its first waste-to-energy facility with heat recovery, and today the vast majority of the households in Copenhagen are heated by district heating supplied through a network reaching more than $40 \mathrm{~km}$ from the city centre, as illustrated in Figure 4. At national level all waste-to-energy facilities for municipal solid waste are connected to district heating networks, and barely any of the generated heat is cooled away.

For the Amager Bakke waste-to-energy facility it was also a requirement that the technical solutions should be well proven and capable of withstanding large variations in waste composition. The stringent environmental requirements and the owner's high environmental ambitions were taken into consideration.

The prospect of being able to sell district heating instead of only power greatly increases the overall energy recovery. As discussed in Tobiasen (2012), a slight reduction of power may be exchanged to a large heat production in a CHP system. One MW of electricity can be exchanged for about $18 \mathrm{MW}$ of district heating in a CHP plant, depending on the chosen system configuration and temperature levels of the district-heating network. An example is given in Figure 5.

Where no district-heating network is available, which is often the case in the UK and elsewhere, power production may be the only option for energy output. These facilities typically have a net efficiency in the range $25-30 \%$ of the lower heating value of the input waste. The power generation efficiency is reduced to $22-28 \%$ in otherwise similar CHP plants, but the district-heating production boosts the total net thermal efficiency to around $85 \%$ from the boiler and turbine condensation system.

Additional heat may be recovered by condensation of the water vapour content of the flue gases, adding up to around $20 \%$ to the thermal efficiency, thereby reaching efficiencies above $100 \%$. Although this appears to conflict with the fundamental laws of thermodynamics, it does not. The explanation is that it is common practice (in Europe) to refer to the thermal efficiency as energy input measured by the lower heating value (LHV) of input waste. This definition implies that the water vapours released during combustion leave the system in an evaporated state. The LHV does, thus, not include the heat of condensation.

When flue gas condensation is applied this precondition is violated and values above $100 \%$ are possible. When the efficiency is calculated with reference to the theoretical energy content represented by the higher heating value, which includes the heat of condensation, the efficiency is around $95 \%$. This reference is used in the USA. The opportunities offered by CHP

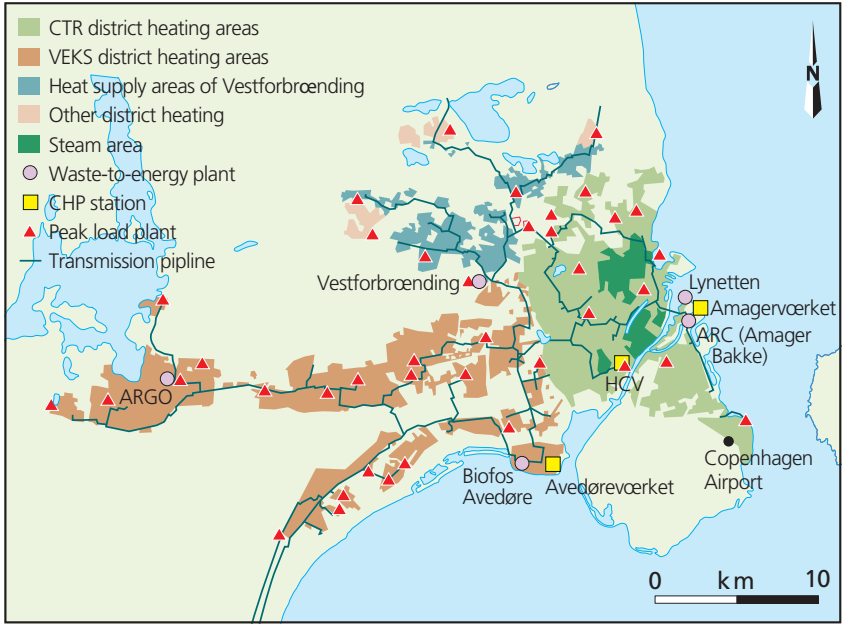

Figure 4. Copenhagen district heating network has several wasteto-energy facilities as well as other CHP plants including peak-load boilers

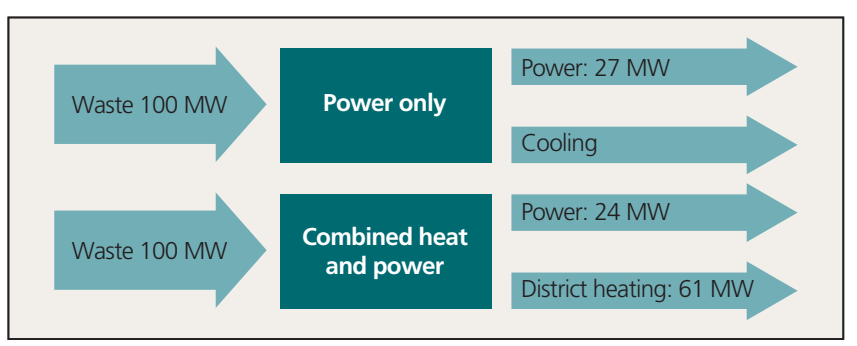

Figure 5. Example comparing energy flows of a power producing waste-to-energy facility and a combined heat and power producing waste-to-energy facility without flue gas condensation

are included in all waste-to-energy facilities in Denmark and most (if not all) in Sweden, and flue gas condensation is applied in most new waste-to-energy facilities in Denmark and Sweden. Flue gas condensation has been retrofitted to several existing facilities, so in Denmark around $70 \%$ of the installed waste-toenergy capacity was equipped with flue gas condensation by the end of 2017.

The main process flow diagram for the Amager Bakke facility can be seen in Figure 6, and the main design parameters are listed in Table 1. The facility has two grate-fired $35 \mathrm{t} / \mathrm{h}$ drum-type boilers supplied by Babcock and Wilcox Vølund (112 MW fired per boiler), a wet flue gas treatment system supplied by LAB including a flue gas condensation system and finally a highly efficient 67 MWe steam turbine SST-800 from Siemens.

Energy recovery and optimisation is an integrated part of the facility. Every optimisation opportunity is weighed on a financial scale and against other criteria given by the framework conditions, and only attractive solutions are included. The main features are as follows.

- High steam parameters: $440^{\circ} \mathrm{C} / 70$ bar, prepared for $480^{\circ} \mathrm{C} / 70$ bar. 
- The boiler operates at low excess air ratio (only $6 \%$ dry oxygen in the flue gas) thus yielding high boiler efficiency.

- A front-end (hot) selective catalytic reduction (SCR) of nitrogen oxides by ammonia means efficient reduction of nitrogen oxides without energy consuming steam-fed flue gas re-heaters that are necessary in systems with a tail-end SCR.

- Low turbine back pressure through large turbine condensers.

- Steam turbine with high isentropic efficiency and many bleeds allow for a complex and efficient water-steam cycle.

- Cooling of flue gas to $160^{\circ} \mathrm{C}$ at the boiler exit.

- Two-step flue gas condensation: first step is cooling the flue gas by heat exchange with the district heating return line, yielding $10 \mathrm{MW}$ of extra district heating per boiler, and second step is cooling the flue gas down to as low as $20-30^{\circ} \mathrm{C}$ by using an absorption heat pump, adding another $15 \mathrm{MW}$ of extra district heating per boiler. In total the flue gas condensation adds more than $20 \%$ to the energy recovery. The projected total net efficiency thereby reaches $107 \%$ (net efficiency means the total production less parasitic consumption relative to the energy content of input waste determined as the LHV).

In addition, the facility is designed to have a very high availability - above $93 \%$ on an annual basis - which is important in relation to waste treatment capability and to continuously harvest the benefit of having high energy efficiency. Having only one turbine does not adversely affect availability in terms of waste treatment capacity or the energy efficiency, because the turbine is not essential for the operation of the plant. The steam may bypass the turbine and condense, and the heat of condensation is transferred to the districtheating networks.

Amager Bakke has a high degree of operational flexibility - the main energy sales options are illustrated in Figure 7. It is possible to sell heat to two of Copenhagen's subsystems in the district heating network: the local distribution system of Hofor, and the transmission network of CTR. This is done in specially developed double tube-bundle condensers.

The turbine has a controlled extraction supplying steam to a heat pump system - which drives the flue gas condensation. Finally, a full turbine bypass system is implemented, thus allowing for very high heat sales in periods with low power prices, or with high heating demands. The resulting main modes of possible operation are

- normal operation with CHP, including direct flue gas condensation

- same as above, but with flue gas condensation boosted by approximately $30 \mathrm{MW}$ with heat pumps in operation

- complete turbine bypass operation with heat pumps in operation.

In addition, there are a number of combinations operating one or two boilers and part or full load. The nominal energy production for two-boiler operation is illustrated in Figure 8 for the rated load of the furnace, corresponding to net outputs $0.7 \mathrm{MWh}(21.9 \%)$ electricity and $2.7 \mathrm{MWh}$ heat (totalling $107 \%)$ per tonne of waste for the expected predominant operating case with heat pumps in operation, referring to an LHV of $11 \cdot 5 \mathrm{MJ} / \mathrm{kg}=3 \cdot 19 \mathrm{MWh} / \mathrm{t}$. The energy outputs represent a

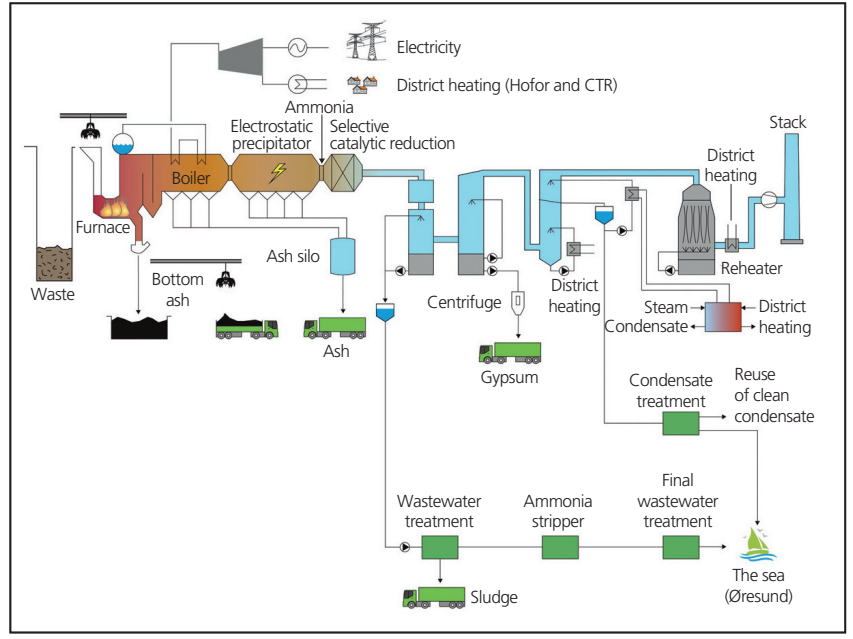

Figure 6. Process flow diagram of the Amager Bakke waste-toenergy facility (showing just one of two boilers)

Table 1. Waste throughput, energy, flue gas flow and composition

\begin{tabular}{|llc|}
\hline Parameter & Unit & Nominal waste \\
\hline Number of boilers & No. & 2 \\
\hline Number of turbines & No. & 1 \\
\hline Waste flow, total & $\mathrm{t} / \mathrm{h}$ & 70 \\
\hline Lower heating value (nominal) & $\mathrm{GJ} / \mathrm{t}$ & 11.5 \\
\hline Lower heating value (range) & $\mathrm{GJ} / \mathrm{t}$ & $8-15$ \\
\hline Thermal energy input, total & $\mathrm{MW}$ & 223.6 \\
\hline Flue gas flow rate, total & $\mathrm{m}^{3} / \mathrm{h}$, ref. & 438000 \\
\hline Moisture content in raw flue gas & $\%$ & 15 \\
\hline Hydrogen chloride $(\mathrm{HCl})$ in raw gas & $\mathrm{mg} / \mathrm{m}^{3}$, ref. & 800 \\
\hline $\begin{array}{l}\text { Sulfur dioxide }\left(\mathrm{SO}_{2} \text { ) in raw gas }\right. \\
\text { ref., reference condition (i.e. } 0^{\circ} \mathrm{C},\end{array}$ & $\mathrm{mg} / \mathrm{m}^{3}$, ref. & 400 \\
\hline $11 \% \mathrm{O}^{2}$ ) & 325 Pa, dry flue gas at \\
\hline
\end{tabular}

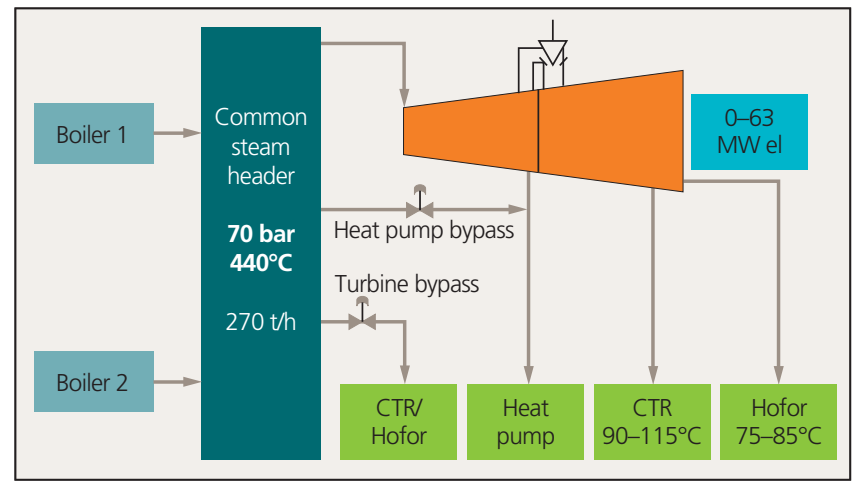

Figure 7. Flexibility regarding heat and power sales

remarkable improvement compared with the old facility, with net electricity efficiency around $17 \%$ and total net thermal efficiency around $83 \%$. 


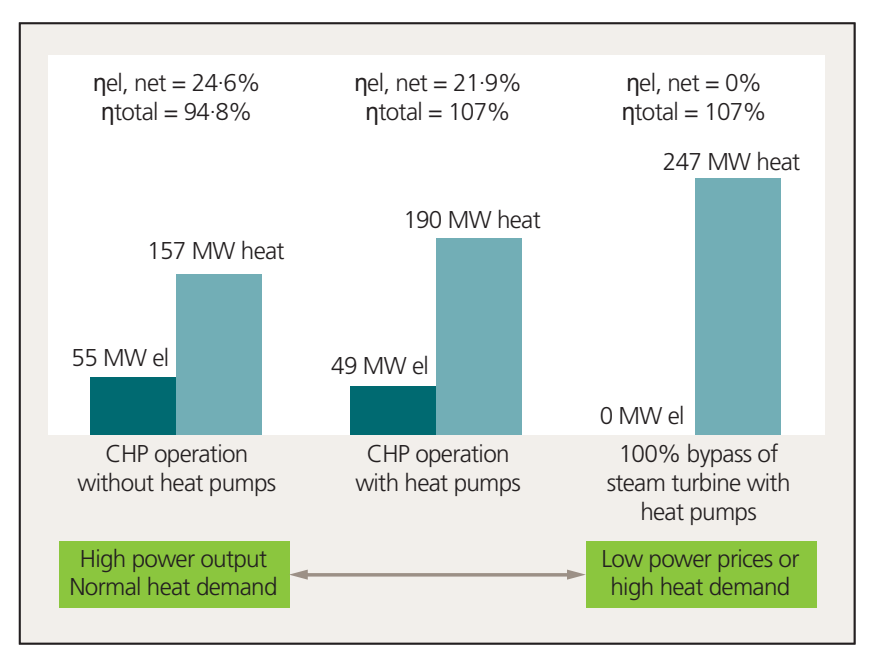

Figure 8. Modes of operation in relation to energy recovery at Amager Bakke - outputs and efficiencies are net after deduction of parasitic consumption (el, electricity)

\section{Environmental performance}

\subsection{Choice of flue gas treatment technology}

The choice of flue gas treatment (FGT) technology was based on a range of criteria applied on a number of potential process configurations and taking into consideration the frame conditions given by the location, ownership and regulatory framework, including environmental requirements. Such requirements are laid down in the environmental permit (Environmental Protection Agency of Denmark, Miljøstyrelsen, 2012) which is based on the industrial emissions directive (EU, 2010) and the note on best available techniques - that is, BAT reference note (or BREF) (EC, 2006). The plant concept should also cope with potential future tightening of requirements, which has been expressed later in a draft revised BREF (JRC, 2017).

The FGT concept includes an SCR system for the abatement of nitrogen oxides, a wet scrubbing system and flue gas condensation. This was deemed attractive because of its high flexibility with respect to increasingly stringent environmental requirements, robustness towards relatively high raw gas (untreated flue gas) pollutant loads, environmentally friendly nature of consumables (limestone instead of burnt lime, in particular), relatively low raw materials consumption, limited amount of solid residues, high energy recovery, possibility of recycling water generated from flue gas condensation and low net present value over the planning period compared with other options despite the relatively high investment that is associated with the advanced FGT system.

It was also of importance that the FGT concept had a solid track record in the field with numerous years of operation and that a sufficient number of qualified suppliers were available.

\subsection{Abatement of nitrogen oxides}

The $\mathrm{NO}_{x}$ abatement concept is a front-end low-dust SCR system with a three-layer catalyst located downstream from a hightemperature four-field electrostatic precipitator (ESP) operating at around $270^{\circ} \mathrm{C}$, which in turn requires the high-pressure economiser of the boiler to be located downstream from the ESP and SCR system in the path of the flue gas. In the system there is no need for flue gas reheating and associated systems, which are draw-backs of conventional tail-end SCR solutions.

The catalyst also destroys dioxins and furans to a level below the emission limit value. The tax on nitrogen oxides emissions facilitated the choice of the highly efficient SCR system over the less efficient conventional SNCR system. SNCR means selective non-catalytic reduction of nitrogen oxides, in which urea or ammonia water is injected to reduce nitrogen oxides at a flue gas temperature of around $900^{\circ} \mathrm{C}$ in the afterburning chamber, by which process nitrogen oxides are reduced without a catalyst. This is the preferred system in the UK and other places, where nitrogen oxides emissions from wasteto-energy need to comply with the industrial emmissions directive (EU, 2010) or similar requirements, and are not subject to taxation or particularly tightened limit values to a level that necessitates the high efficiency that only the SCR can provide.

\subsection{Wet scrubbing system}

The four-stage wet scrubbing system removes in the first stage hydrogen chloride $(\mathrm{HCl})$, hydrogen fluoride (HF) and most of the heavy metals which have not been completely captured by the ESP. Sulfur dioxide is removed in the second-stage limestone scrubber, and two-stage flue gas condensation not only ensures heat recovery, but it also provides additional two-stage polishing of the flue gas including an additional dioxin and mercury removal stage through injection of activated carbon. The outstanding efficiency of the flue gas treatment system barely leaves a trace of pollutants in the flue gas when emitted into the ambient air - see Table 2 and Figure 9.

\subsection{Condensate and process wastewater}

Recovery of the heat of condensation in the flue gas condensation stages comes with removal of water vapour from the flue gas, which is turned into liquid water. In essence, this is distilled water, a valuable product that is a source of water for the entire facility and for potential purposes outside the facility such as make-up water to cover the water loss of the district heating network of Copenhagen.

The amount of excess condensate for export corresponds to around $40 \%$ of the incoming waste, when the flue gas condensation is in full operation.

Treated wastewater and excess condensate (if not recycled for internal and external purposes) are discharged to the adjacent sea, Øresund (translated into English as the Sound), between Denmark and Sweden. Its treatment must comply with very stringent requirements for discharge, Table 3 and Figure 10. These requirements surpass the EU directive (EU, 2010) limit values for most heavy metals by a factor of 10 or more and even surpass drinking water requirements on several parameters.

The wastewater discharge therefore represents hardly any mass flow of pollutants and no environmental impact for all practical purposes. Prior to discharge, the process wastewater is treated in a conventional precipitation system, supplemented by a fine treatment with sand filters, carbon filters and ion exchangers and ammonia strippers that recycle the liberated ammonia to the furnace. Condensate is treated in its own system including reverse osmosis to produce very clean water that is virtually free of salt and pollutants. In principle the condensate water is too valuable just to discharge. It is made available for use as make-up water for the boilers, district heating network and other industrial applications. 
Table 2. Flue gas emissions (daily average/spot): EU industrial emissions directive (EU, 2010), environmental permit (Danish Environmental Protection Agency, 2012) and expected operational emissions

\begin{tabular}{|c|c|c|c|}
\hline Air emission, daily average $\mathrm{mg} / \mathrm{m}^{3}$, ref. & $\begin{array}{l}\text { EU industrial } \\
\text { emissions directive }\end{array}$ & Environmental permit & $\begin{array}{l}\text { Expected operational } \\
\text { emissions }\end{array}$ \\
\hline Carbon monoxide (CO) & 50 & 39 & 10 \\
\hline Total organic carbon & 10 & 8 & 1 \\
\hline Dust & 10 & 5 & 3 \\
\hline Hydrogen chloride $(\mathrm{HCl})$ & 10 & 5 & 0.5 \\
\hline Hydrogen fluoride (HF) & 1 & 1 & 0.05 \\
\hline Sulfur dioxide $\left(\mathrm{SO}_{2}\right)$ and sulfur trioxide $\left(\mathrm{SO}_{3}\right)$ (as sulfur dioxide) & 50 & 30 & 2 \\
\hline Nitric oxides $\left(\mathrm{NO}_{\mathrm{x}}\right)$ (as nitrogen dioxide $\left(\mathrm{NO}_{2}\right)$ ) & 200 & 100 & 15 \\
\hline Ammonia $\left(\mathrm{NH}_{3}\right)$ & - & 3 & 0.5 \\
\hline Nitrogen dioxide $\left(\mathrm{N}_{2} \mathrm{O}\right)$ & - & - & 0.5 \\
\hline Cadmium $(\mathrm{Cd})+$ thallium $(\mathrm{Tl})$ & 0.05 & 0.025 & 0.001 \\
\hline Sum of nine metals ${ }^{a}$ & 0.5 & 0.25 & 0.015 \\
\hline Mercury $(\mathrm{Hg})$ & 0.05 & 0.025 & 0.001 \\
\hline Polycyclic aromatic hydrocarbons & - & 0.0025 & 0.002 \\
\hline Dioxins and furans, TEQ (ng/m³, ref.) & 0.1 & 0.1 & 0.02 \\
\hline
\end{tabular}

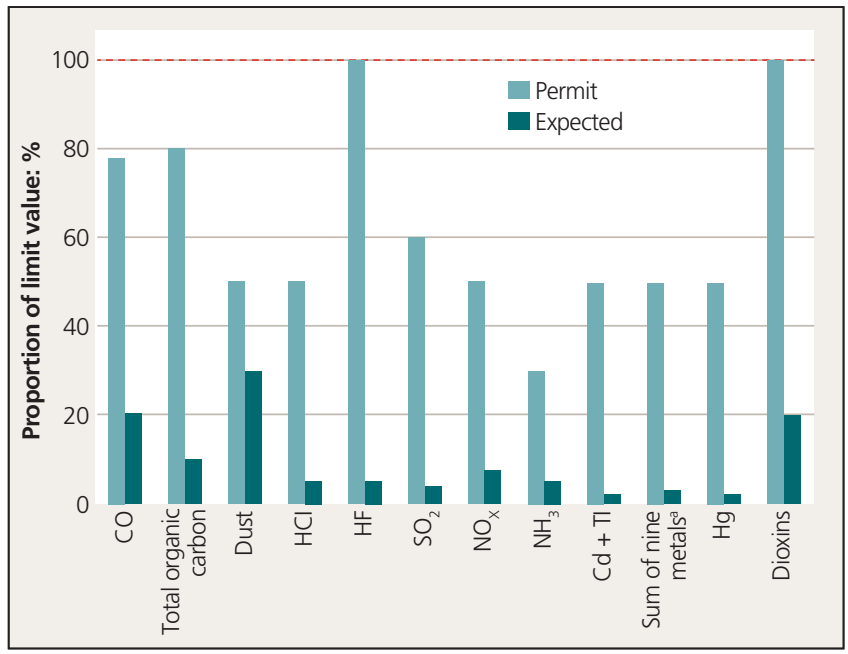

Figure 9. Flue gas emissions (data as Table 2). antimony (Sb), arsenic $(\mathrm{As})$, lead $(\mathrm{Pb})$, cobalt $(\mathrm{Co})$, chromium $(\mathrm{Cr})$, copper $(\mathrm{Cu})$, manganese $(\mathrm{Mn})$, vanadium $(\mathrm{V})$ and nickel $(\mathrm{Ni})$

\subsection{Consumables and FGT as a whole}

The use of SCR for deNO ${ }_{x}$ and a wet FGT process limit the amounts of consumables and residues to a level close to the theoretical minimum. In Table 4, the values are seen together with the flue gas flow rate and relatively high pollutant load in the raw, untreated flue gas (Table 1), and the expected flue gas treatment efficiency (Table 2). One of the features of wet scrubbing is that the chlorine content of the input waste leaves the facility in an aqueous chloride solution, representing little environmental impact when discharged to the sea. This replaces a large share of the solid residue that would otherwise be generated in conventional dry/semi-dry FGT systems that are predominant in the UK and in many other countries.

\section{Waste treatment, materials recovery and recycling}

Optimal resource management is a key topic in waste management. At the Amager Bakke waste-to-energy facility the incineration process provides the opportunity for further material recycling from the input residual waste, which in itself is the result of source segregation and considered depleted of recyclable materials. The additional recycling therefore represents recovery of resources that would not otherwise be recycled. The incineration process converts the combustible matter to hot flue gas from which energy is recovered and converted into heat and power. Output streams are presented in Figure 11.

The incombustible matter including metals leaves the facility mainly as bottom ash. Metal segregation from bottom ash is expected to reach more than $90 \%$ of the potential for most ferrous and non-ferrous metals when modern techniques are deployed. Such techniques include pre-sorting by sieving the bottom ash into narrow particle ranges, where every particle fraction is sorted by magnet separators and eddy current separators.

The segregated raw metal mixtures are further processed by a specialised company to yield sellable grade metals through use of highly efficient eddy current separators and X-ray based separators. Few other metal segregation systems for municipal solid waste management would be expected to reach similar efficiency. When waste is sorted, much metal is not recovered because it is embedded in other materials; for example in plastics or tissues. Source segregation of waste is subject to the same limitation and the precision of the 
Table 3. Wastewater requirements (extract), process wastewater and condensate, respectively: environmental permit (Danish Environmental Protection Agency, 2012), EU industrial emissions directive (EU, 2010), BAT reference note (EC, 2006) and drinking water values for comparison (Danish Ministry of the Environment, 2016)

\begin{tabular}{|c|c|c|c|c|c|c|}
\hline Parameter & Unit & $\begin{array}{l}\text { EU industrial } \\
\text { emissions } \\
\text { directive } \\
\text { limit values }\end{array}$ & $\begin{array}{l}\text { BREF, BAT } \\
\text { operational } \\
\text { levels }\end{array}$ & $\begin{array}{l}\text { DK drinking } \\
\text { water limit } \\
\text { values (at tap) }\end{array}$ & $\begin{array}{l}\text { Environmental } \\
\text { permit, process } \\
\text { wastewater } \\
\text { discharge }\end{array}$ & $\begin{array}{l}\text { Environmental } \\
\text { permit, } \\
\text { condensate } \\
\text { discharge }\end{array}$ \\
\hline $\mathrm{pH}$ & - & - & $6.5-11$ & $7-8.5$ & $6.5-9.0$ & $6.5-9.0$ \\
\hline Suspended matter (100\%) & $\mathrm{mg} / \mathrm{l}$ & 45 & $10-45$ & - & 30 & 30 \\
\hline Suspended matter (95\%) & $\mathrm{mg} / \mathrm{l}$ & 30 & $10-30$ & - & - & - \\
\hline Mercury $(\mathrm{Hg})$ & $\mu g / l$ & 30 & $1-30$ & 1 & 1 & 0.1 \\
\hline Cadmium $(C d)$ & $\mu g / l$ & 50 & $10-50$ & 5 & 3 & 1 \\
\hline Thallium (TI) & $\mu g / l$ & 50 & $10-50$ & - & 3 & 2 \\
\hline Arsenic (As) & $\mu g / l$ & 150 & $10-150$ & 10 & 8 & 5 \\
\hline Lead (Pb) & $\mu g / l$ & 200 & 10-100 & 10 & 10 & 1 \\
\hline Chromium (Cr) & $\mu g / l$ & 500 & $10-500$ & 50 & 10 & 3 \\
\hline Copper (Cu) & $\mu g / l$ & 500 & $10-500$ & 2000 & 10 & 5 \\
\hline Nickel (Ni) & $\mu g / l$ & 500 & $10-500$ & 20 & 10 & 3 \\
\hline Zinc (Zn) & $\mu g / l$ & 1500 & $10-1000$ & 3000 & 300 & 50 \\
\hline Dioxins and furans, TEQ & $\mathrm{ng} / \mathrm{l}$ & 0.3 & $10-100$ & - & 0.01 & 0.01 \\
\hline Temperature & ${ }^{\circ} \mathrm{C}$ & - & - & - & 50 & 30 \\
\hline Reference flow per tonne waste input & $1 / \mathrm{t}$ & & & & 110 & 360 \\
\hline DK, Denmark; TEQ, toxicity equivalents & $(\mathrm{EU}, 2 \mathrm{C}$ & & & & & \\
\hline
\end{tabular}

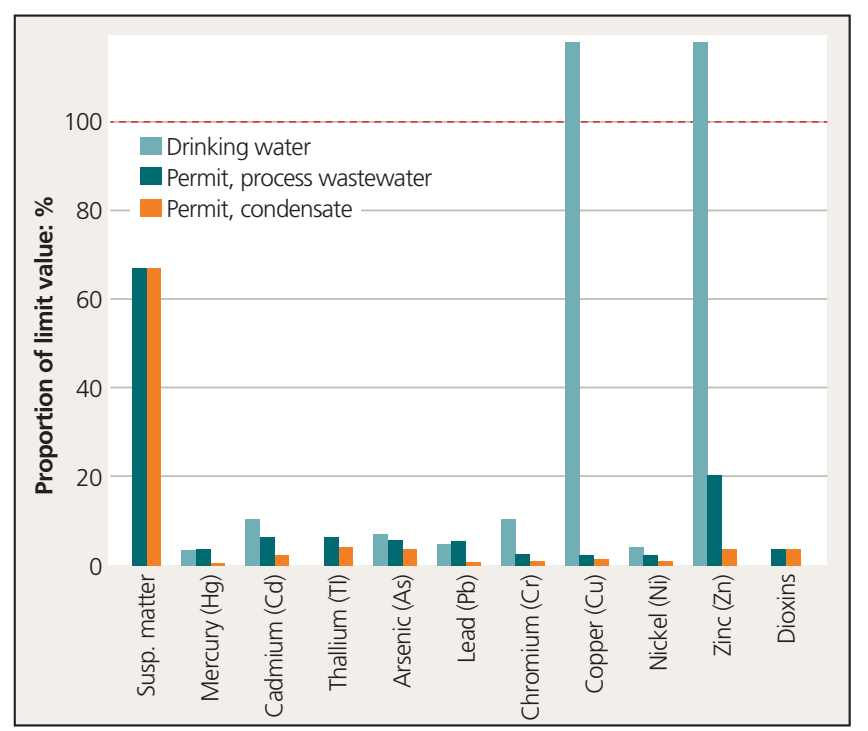

Figure 10. Wastewater requirements (data as Table 3).

human operators. The incineration process removes the surrounding materials, making the ferrous and non-ferrous metal accessible for mechanical segregation from the bottom ash.

Recovery of metals from the bottom ash is therefore essential for reaching high metal recovery efficiency when considering the waste management system as a whole. The recovered metals are sold at high prices to replace virgin materials. The bottom ash is used for road construction and similar construction purposes under
Table 4. Expected consumption data and residues production per tonne of input waste

\begin{tabular}{llc}
\hline Mass flows & Unit & $\begin{array}{c}\text { Expected } \\
\text { consumption/ } \\
\text { production }\end{array}$ \\
\hline Ammonia water (25\%) & $\mathrm{kg} / \mathrm{t}$ & 3.0 \\
\hline Limestone (95\% calcium carbonate) & $\mathrm{kg} / \mathrm{t}$ & 12 \\
\hline Sodium hydroxide (NaOH) (27\%) & $\mathrm{kg} / \mathrm{t}$ & 1 \\
\hline Activated carbon & $\mathrm{kg} / \mathrm{t}$ & 0.3 \\
\hline $\begin{array}{l}\text { Other (terthiophene, iron (III) chloride } \\
\text { (FeCl3)), flocculant, anti-scalant) }\end{array}$ & $\mathrm{kg} / \mathrm{t}$ & 0.04 \\
\hline Hydrogen chloride (HCl) & $\mathrm{kg} / \mathrm{t}$ & 0.5 \\
\hline Water consumption* & $\mathrm{l} / \mathrm{t}$ & 0 \\
\hline Electrical power consumption & $\mathrm{kWh} / \mathrm{t}$ & 105 \\
\hline Production/discharge & & \\
\hline Bottom ash & $\mathrm{kg} / \mathrm{t}$ & 150 \\
\hline Recovered metals & $\mathrm{kg} / \mathrm{t}$ & $10-15$ \\
\hline Process wastewater for discharge & $\mathrm{l} / \mathrm{t}$ & 110 \\
\hline $\begin{array}{l}\text { Condensate discharge or export for } \\
\text { recycling }\end{array}$ & $\mathrm{l} / \mathrm{t}$ & 400 \\
\hline Fly ash & & $15-20$ \\
\hline $\begin{array}{l}\text { Gypsum } \\
\text { Hydroxide sludge (dry matter) }\end{array}$ & $\mathrm{kg} / \mathrm{t}$ & 5 \\
\hline awith flue gas condensation in full operation & 2 \\
\hline & $\mathrm{kg} / \mathrm{t}$ & \\
\hline
\end{tabular}




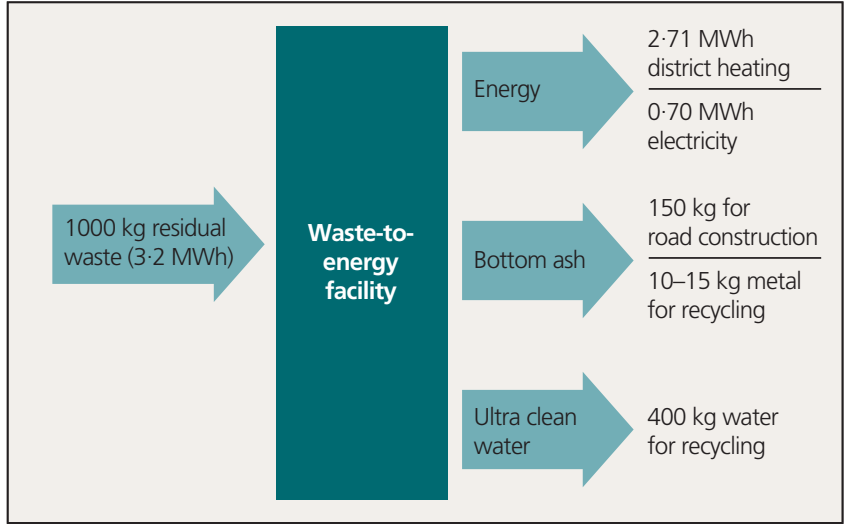

Figure 11. Summary of outputs from Amager Bakke

stringent requirements for its use, its heavy metal content and its leaching behaviour. Thereby the bottom ash replaces natural resources of similar nature - that is, sand and gravel.

Other solid total residues total around $20-30 \mathrm{~kg}$ per tonne of incoming waste and include fly ash segregated in the ESP, gypsum formed by absorption of sulfur dioxide by limestone in the scrubbing system and sludge from treatment of process wastewater. These are used for neutralisation of other industrial residues and disposed of in a landfill for hazardous waste.

The water contained in the waste is recovered in the flue gas condensation stage and is foreseen to replace other water resources; for example for covering the losses of the district heating network. No other known treatment processes recover clean water. The total 'true recycling' from the incineration of residual waste would thereby exceed $50 \%$ of incoming waste.

According to current EU definitions of 'recycling' none of these activities are considered 'recycling' as the waste-to-energy facility as such is defined as a 'recovery' operation from which no 'recycling' is officially possible (it is, however, possible that recycled metals may be counted as 'recycled' in the future). This illustrates that EU and government recycling targets based on total mass according to the definitions used hitherto give little information on the true resource recovery, let alone the true resource value of the recycled materials in terms of saved virgin resources.

\section{Summary}

The Amager Bakke waste-to-energy facility was in the final stages of commissioning by the start of 2018 (about to start trial run) and once in commercial operation it will provide a combined solution to several challenges in Copenhagen, and may serve as an example of future opportunities for cities around the world.

The large construction located in the centre of the city is made available for recreational purposes such as an all-year skiing slope, a climbing wall and a viewpoint. The residual waste of the city is treated locally, limiting transport.

The energy recovery from the waste with a projected total thermal net efficiency of around $107 \%$ reaches unprecedented levels facilitated by the integration in the city with its district- heating network and a highly sophisticated technology of the CHP facility, featuring among other things a back-pressure turbine with multiple steam outlets for district-heating generation and recovery of heat by flue gas condensation assisted by absorption heat pumps.

The waste-to-energy facility is also an important tool for material recycling through recovery of metals from bottom ash, use of bottom ash for construction purposes and export of clean water.

\section{Acknowledgements}

The authors thank their many colleagues from ARC and Ramboll for sharing their insight in and experiences from the conceptual design, planning, tendering, construction, supervision, commissioning and testing of the new facility. They particularly thank Ole Poulsen, who led the Ramboll team. They also thank Patrik Gustavsson, Director at the Amager Bakke Foundation, for his input to the wording of the section on the recreational opportunities. Their gratitude also goes to all the municipalities and companies involved and their staff, amounting to several thousand people in total; without their contribution no plant could have been built, and no paper could have been written.

\section{References}

ARC (Amager Resource Center) (2017) Hoved- og Nøgletal. See https://www.a-r-c.dk/om-arc/hoved-og-noegletal (accessed 19/12/2017) (in Danish)

Danish Environmental Protection Agency (2012) Miljøgodkendelse Amagerforbrænding. See http://mst.dk/media/95451/AMF6_ Miljogodkendelse_Amagerforbraending.pdf (accessed 19/12/2017) (in Danish).

Danish Ministry of the Environment (2016) BEK nr 802 of 01/06/2016, Bekendtgørelse om vandkvalitet og tilsyn med vandforsyningsanlæg. See https://www.retsinformation.dk/Forms/R0710.aspx?id=180348 (accessed 05/09/2017) (in Danish).

EC (European Commission) (2006) Integrated Pollution Prevention and Control. Reference Document on the Best Available Techniques for Waste Incineration, August 2006. See http://eippcb.jrc.ec.europa.eu/reference/ wi.html (accessed 05/09/2017).

EU (2010) Directive 2010/75/EU of the European parliament and of the council of 24 November 2010 on industrial emissions (integrated pollution prevention and control). Official Journal of the European Union L334: 17-119.

Gustavsson P (2017) Fonden Amager Bakke. See www.facebook.com/ Copenhill (accessed 07/2017)

JRC (Joint Research Centre) (2017) Best Available Techniques (BAT) Reference Document on Waste Incineration (Draft 1). European Union, Brussels, Belgium. See http://eippcb.jrc.ec.europa.eu/reference/BREF/WIMI_5_2405-2017_web.pdf (accessed 05/09/2017)

Tobiasen LK (2012) Waste-to-energy for district heating. In Encyclopedia of Sustainability Science and Technology (Myers RA (ed.)). Springer, NY, USA.

\section{How can you contribute?}

If you would like to comment on this paper, please email up to 200 words to the editor at journals@ice.org.uk.

If you would like to write a paper of 2000 to 3500 words about your own experience in this or any related area of civil engineering, the editor will be happy to provide any help or advice you need. 